\title{
Plants of the Northern Temperate Zone in their Transition to the High Mountains of Tropical Africa.
}

BY

\section{A. ENGLER.}

IN building up the theories of the evolution of species, those plants which are either fully identical or appear as closely allied forms in widely separated localities, have always received special attention. It is known that it is not unusual to find one and the same species or nearly related ones in the northern as well as in the southern extra-tropical regions. Further, it is well known that these facts may be accounted for by the similar climates in similar latitudes, by the changing of area of hekistothermic or mesothermic plants during the glacial period or after it, by the wholesale extinction of species during that period owing to lack of resistance or their inability to adapt themselves to the new conditions of life.

Still, there remains a large number of cases of species or nearly allied ones which are disjointedly distributed in meridional direction across the equator. Sir Joseph Hooker, in his memorable Introductory Essay to the Flora of Tasmania, was the first to call attention to the species occurring at the south corner of America which are identical with those of the arctic or northern temperate zone. The same author was the first to give a list of the so-called European types on Cameroon Peak.

Later on, species of the same character were found on the Kilimanjaro and other high mountains of tropical East Africa.

As a result of the botanical investigation of Africa, a considerable number of highland forms have been recorded whose nearest relatives are to be looked for partly in the boreal region, partly in other widely separated countries. Also at lower altitudes several species are to be found which appear in regions far distant from Africa.

In regarding those plants, the following questions must always be borne in mind :

I. Are they identical with the forms living in other latitudes, or do they show any small variation from them? 
2. Is there any possibility of their having originated from a species which was once distributed throughout the intermediate area between the present localities, or in the lower regions, and having developed themselves into identical or convergent highland-forms in the higher regions? Or is it only to be supposed that the seeds have been brought by birds or wind across so many degrees of latitude?

3. What are the means of transportation of seeds and fruits?

4. What is the power of germination? especially, how long are the seeds able to keep it?

5. How do the plants cultivated in Europe from tropical seeds compare with their closest relatives which are indigenous to Europe?

No experiments in answer to questions 4 and 5 have yet been instituted. But whatever the results may be, they will not be able to unsettle the assumption of the close affinity of an African plant to a European one when based upon morphological comparison.

If of two nearly allied forms, $A e$ in Europe and $A a$ in Africa, the seeds of $A a$ when cultivated in Europe give the form $A e$, it is proved that the evolution of $A e$ is only due to climatic conditions. But if the seeds of $A a$ again give $A a$, the assertion of $A a$ having once originated from $A e$ is not by any means refuted : for the transformation of $A a$ into $A e$ may well have become fixed during a long period. However, it is much to be recommended that many such experiments of cultivation should be made.

Regarding question 2, the answer is given for those plants which are isolated in the high mountains of Africa, whereas there are many closely allied forms in Europe. This answer is definitely settled in the case of those species whose European forms belong to a larger group of related plants developed in Europe or in the northern temperate zone generally.

From these, I shall select for discussion principally such forms as, not being represented in Egypt, are to be found only in Abyssinia or further south.

Since the first travels of Schimper in Abyssinia, we are acquainted with a species of Luzula, growing at 3,600 m. above sea-level, which was named L. spicata, (L.) DC., var. simensis, Hochst. This plant was found, later on, on the Kilimanjaro also. On the same mountain, another one was collected by Prof. Volkens and described as L. Volkensii by Prof. Buchenau. This Luzula seemed to be worthy of more careful examination, since any forms at all closely related to L. spicata, (L.) DC., are absent from tropical Africa (as well as from Southern Africa). Luzula spicata itself is an arctic-alpine plant, and arctic-alpine plants are not observed elsewhere in tropical Africa.

When visiting the Kilimanjaro in October I902, I had the first opportunity of observing these plants on a meadow below the Muë River, at about $\mathrm{x}, 900-2,000 \mathrm{~m}$., in company of other plants more frequently to be met 
with in the grass-region above $2,900 \mathrm{~m}$. Of a Luzula about $25-60 \mathrm{~cm}$. high, I saw here smaller specimens with leaves $3 \mathrm{~mm}$. wide, which are very much like a Luzula spicata, (L.) DC., such as is found on the Schneekoppe, Riesen-Gebirge-the more so when exceptionally the inflorescence happens to be not erect but slightly pendulous. Afterwards, in the same meadow as well as on the grassy slopes above $2,900 \mathrm{~m}$. up to $3,100 \mathrm{~m}$, I found other forms with taller stems (up to $70 \mathrm{~cm}$.) and wider leaves $(5-10 \mathrm{~mm}$.). Between these extremes noted there exist all intermediate forms, just as one may find specimens of Luzula of $5-40 \mathrm{~cm}$. in height and with leaves from I-3 $\mathrm{mm}$. wide growing closely together in the same range of the Alps.

Great variation is shown also in the foliation of the stem by the Luzula of the Kilimanjaro. Some of them have the uppermost leaf about I5$20 \mathrm{~cm}$. below the inflorescence, this leaf being narrow-linear, only about $5 \mathrm{~cm}$. long by I mm. wide ; in other cases, the uppermost leaf is $2-3 \mathrm{~mm}$. wide, up to $10 \mathrm{~cm}$. long, closely beset with long hairs at the lower margin, and also borne nearer to the inflorescence: such specimens being very similar to L. spicata, (L.) DC., var. simensis, Hochst.

Besides, there are to be found specimens about $15^{-20} \mathrm{~cm}$. high not yet fully developed. Their stem is completely covered by the sheathing leaves which, together with the bracts, overtop the crowded inflorescence, still about $3 \mathrm{~cm}$. long; these leaves being long-pilose at the edge, the inflorescence is completely enclosed by the spreading hairs. Such specimens had been described as L. Volkensii by Prof. Buchenau. By studying the specimens collected by myself and Prof. Volkens and comparing them with L. spicata, (L.) DC., observed by me repeatedly in Northern and Southern Europe, I obtained the following results:

Luzula spicata is to be found in the whole arctic and sub-arctic belt, in Scotland, the Riesen-Gebirge, the Jura, the Auvergne, the Cevennes, from the Pyrenees through the Alps to the Carpathian Mountains; also in the Sierra Nevada, Corsica, Sardinia, Albania, the Pindus, Balkan Mountains, Thracia, on Mount Olympus, Bithynia, and the mountains of Pontus, Mount Ida, Mount Argaeus, Cappadocia, at 3,200 m., moreover in the Altai and Alatan Mountains, in Turkestan, the Cashmere at $4,200 \mathrm{~m}$. In North America beyond the arctic region, it is found on the White Mountains, on the Rocky Mountains of Montana at 3,000 m., and of Colorado at $4,000 \mathrm{~m}$. By comparing specimens from these localities, it is evident that the same forms of Luzula spicata are produced in far distant localities, and that the same region produces very different forms. I have myself collected forms with leaves $2-3 \mathrm{~cm}$. long and I $\mathrm{mm}$. wide, and with inflorescences $6-8 \mathrm{~mm}$. long, at the North Cape as well as in Vallée d'Eynes, Pyrenees.

But in the same locality in the Pyrenees specimens may also be seen $\mathrm{O}$ o 2 
with leaves $10-12 \mathrm{~cm}$. long by $\mathrm{I}-2.5 \mathrm{~mm}$. wide and inflorescences $3 \mathrm{~cm}$. long. I have seen specimens with leaves $3 \mathrm{~mm}$. wide from several localities of the Alps, of the Sudetic Chain, and from Colorado. Here and there, the tepals are pale-brown, but as a rule only forms with dark brown tepals are to be found in all the different districts of the area.

Very low forms with a short, compact inflorescence are to be seen in the Alps, the Altai mountains, and in Cashmere side by side with other forms. The inflorescence is always bent to one side, the growth is always densely tufted, the upper cauline leaves are acute, but the basal leaves obtuse. The plant never occurs below the subalpine region except in the arctic belt. No allied plant is to be found in the plains throughout the temperate zone of the northern hemisphere.

From these facts, the supposition presents itself that the species originated in the arctics, where it has developed the physiological quality of growing only in regions with long periods of vegetative rest. On the other hand, its occurrence in distant mountains of the Mediterranean region not having been connected with the Pyrenees, Alps, or Carpathian Mountains, even during the glacial period, appears to suggest the assumption that the seeds have been transported over long distances by some means or other. They are too large for distribution by wind ; there remains, then, distribution by birds. This supposition is only hypothetical for the present, but is supported by other species of Luzula growing often in localities far distant from the main area of the species.

It seems, then, quite safe to accept the view expressed by Buchenau (in Engler's Botan. Jahrb., xii, I30) that the Abyssinian plant belongs as a variety, simensis, Hochst., to L. spicata. Further, if the Abyssinian plant belongs to this species as a variety, it is obvious that L. Volkensii belongs to it also.

All these African forms, however, differ from all the other forms of L. spicata in having stolons, in their obtuse leaves and bracts, and in the inflorescence being erect not pendulous. I hold the opinion, then, that the African plant must be contrasted, under the name of $L$. abyssinica, Parlat., with the widely distributed L. spicata. To this species are to be reckoned as varieties, the var. kilimandscharica, Engl., a tall plant of $60 \mathrm{~cm}$. which ascends up to 3,600 m., and the var. Volkensiz, (Buchenau) Engl., which grows at $3,700-3,900 \mathrm{~m}$.

There is no doubt that this variety is produced by the climatic conditions prevailing in the upper regions of the Kilimanjaro, which retard the prolific development of stolons.

$L$. abyssinica appears never to have advanced further south. In fact, there is no country in the Eastern hemisphere, except New Zealand, where the type of $L$. spicata has developed itself further.

It is otherwise in America. Here we observe Luzula spicata spread as 
far as the Rocky Mountains of Colorado. Again, in the mountains of Mexico we find L. racemosa, growing always at the considerable altitude of $3,000-4,500 \mathrm{~m}$. In its narrow leaves, the acute cauline leaves and pendulous inflorescences, this plant appears even more similar to the L. spicata than L. abyssinica, Parlat.; it grows also tufted just in the same way as $L$. spicata. But it has mostly rigid leaves, revolute at the edge, and three stamens only.

The facts of distribution and the relations of affinity of the species allied to $L$. spicata lead me to the hypothesis that $L$. spicata, after having originated in the Northern hemisphere, was widely distributed in the mountainous parts of it as well as throughout the arctic circle; that it advanced along the Andes of North America as far as Mexico, where it was transformed into L. racemosa, and further that from this other peculiar species have branched off. It is not only on the mountains connected by an arctic-alpine flora during the glacial period that $L$. spicata was distributed, but also on the mountains further south, isolated from the continuous arctic-alpine flora. To the east, it appears to have not advanced beyond the Himalaya Mountains. When passing over to Abyssinia, only few transformations took place: the inflorescence became erect, the basal axillary shoots were prolonged like stolons, and the cauline leaves became obtuse like the basal leaves: from these characters, Buchenau is inclined to believe L. abyssinica, Parlat. (L. spicata var. simensis), an hybrid of L. spicata and campestris (cf. Engler's Botan. Jahrb., xii, I30). From Abyssinia to Kilimanjaro our plant had to travel a long distance; but it is not impossible that it either still exists or has existed previously on a few of the high mountains between Abyssinia and Kenia, from which, having advanced to the Kilimanjaro, it again produced new forms not much differentiated up to the present. At any rate, it is impossible to do without distribution of seeds of alpine plants by air-currents or by birds from one mountain to the other in explaining the history of distribution.

I wish only briefly to mention the two other types of Luzula which have reached tropical Africa. L.campestris, (L.) DC., var. Mannii, Buchenau, on Fernando Po, at 2,700 m., and on Cameroon Peak, at 3,000-4,300 m., shows deviations from the Euro-asiatic forms of $L$. campestris, somewhat in the same direction as L. abyssinica from L. spicata. The growth is taller and the leaves are more vigorous.

$L$. Fohnstonii, Buchenau, also holds about the same relation to L. Forsteri as $L$. abyssinica does to $L$. spicata; it has stolons, L. Forsteri not; its inflorescence is richer than ordinarily in $L$. Forsteri; but specimens from Florence and from Tenerife are fully as many-flowered as L. Fohnstonii, Buchenau, of the Kilimanjaro, where it occurs in the uppermost region of the forest-belt and in the upward extensions of forest between 2,500 and $2,900 \mathrm{~m}$. 
Of the genus Anthoxanthum two plants have been found lately in the mountains of East Africa. The first one, collected by Prof. Volkens near streamlets of the Kilimanjaro at 2,700-2,730 m., was described as A. nivale, K. Schum. The other one, growing on Lukwangula Plateau, Uluguru Mountains, at $2,300 \mathrm{~m}$, has been designated as $A$. monticola, K. Schum. in MS. Dr. Pilger of the Berlin Botanic Museum has carefully compared both these plants with $A$.odoratum, L., which is distributed from Europe to Algeria, but is not recorded from Abyssinia so far. He arrives at the conclusion that the Uluguru plant belongs to $A$. odoratum. He finds the European forms of $A$. odoratum having smaller spikelets, shorter awn, and the second and third palea more hirsute as a rule, but he has found a specimen collected near Dürkheim, Palatinate, by A. Braun having spikelets and awns just as large as those of the Uluguru plant. On the other hand, Anthoxanthum nivale, K. Schum., although very different from $A$. odoratum, is more nearly related to this species than to any other. It is necessary to consider separately the specimens collected at $2,700 \mathrm{~m}$. from those grown at $3,700-3,900 \mathrm{~m}$. Both of them are perennial, having rhizomes and short stolons. The specimens grown at $2,700 \mathrm{~m}$. have sheaths I $5 \mathrm{~cm}$. long, thickened upwards and pilose, and leaves of the same length and 5-7 mm. wide, as is found in Anthoxanthum odoratum only very rarely. The panicle is similar to that of the European plant in a young stage, but is elongated afterwards to $9-12 \mathrm{~cm}$, at the same time becoming looser and developing distant lateral branches. The first glume is rather larger than usual, reaching as it does beyond the middle of the spikelet. Several of the differences stated are to be found occasionally in European forms also, more particularly in f. umbrosum, Bluff; but the perennial growth and the longer outer glume are entirely peculiar to $A$. nivale.

The specimens grown near melting snow at $3,700-3,900 \mathrm{~m}$. have the sheaths shorter and still wider, the lamina up to $\mathrm{I} \mathrm{cm}$. wide, the panicles elongated to $15 \mathrm{~cm}$. and loose below, the glumes still darker coloured; the rhizome is also more robust.

We have, then, a well-distinguished species whose ancestors could spread to the high mountains of Africa from the northern temperate zone only, but have taken a peculiar course of development under the climatic conditions of the upper Kilimanjaro.

Another grass which has spread from the north temperate zone to Africa is Koeleria cristata, (L.) Pers. It is to be found in Abyssinia, the Kilimanjaro, and Cameroon Peak. This plant is absent from the lower regions in the same manner as Anthoxanthum. Specimens collected in Abyssinia on the slopes of Mount Silke may be named as var. convoluta (Hochst.), but it seems to be impossible to separate them from our Koeleria cristata. The young leaves are flat, only the older ones becoming convolute. The panicles are sometimes loose like those of $K$. cristata var. 
lobata, Marss. In higher altitudes at the summit of M. Silke, M. Bachit, M. Dedjen at $3,000 \mathrm{~m}$. to about $4,500 \mathrm{~m}$., the plant does not grow taller than to $10-20 \mathrm{~cm}$., the panicle being more contracted. It is the species of grass which ascends to the highest altitudes. On the Kilimanjaro, from $2,700-3,200 \mathrm{~m}$., we find a robust form, $50-70 \mathrm{~cm}$. high, with a many-flowered panicle $10 \mathrm{~cm}$. long. At the altitude of $3,600 \mathrm{~m}$., in the uppermost region of Ericinella, we find specimens of nearly the same height, with a pubescent rhachis and a long but condensed panicle, which, shading into violet, recalls Anthoxanthum nivale, K. Schum., to some extent. Very similar, somewhat smaller, specimens were collected in Abyssinia at Guna at 3,900 m. Finally, on the Kilimanjaro, being the last grass on lava-fields at $4,500 \mathrm{~m}$., a variety I $5-18 \mathrm{~cm}$. high makes its appearance and is called var. supina by Dr. Pilger. This variety forms thick, unusually dense tufts, having rigid, much convolute basal leaves, flatter cauline leaves, and a narrow panicle $5-7 \mathrm{~cm}$. long, with frequently glabrous rhachis. On the Cameroon Peak, only tall forms of Koeleria cristata have been collected so far, which have rather loose or more contracted panicles and flat or convolute leaves. In conclusion, it may be mentioned that a form of $K$. cristata, (L.) Pers., somewhat different from the above, having leaves partly flat, partly convolute, and a contracted panicle, var. gracilis, Hack., grows on Devil's Peak, near Capetown. We see, then, again a plant, which, having reached Africa from Europe, appears in varieties and forms somewhat different from those produced in Europe.

Among the species which came from the northern temperate zone to the mountains of Africa, Arabis albida, Stev. (1812), being known also as A. caucasica, Willd. ${ }^{1}$ (I8I 3 ), a later synonym, is a very remarkable instance. While holding this species sufficiently distinct from $A$. alpina, I have no doubt that the forms attributed as varieties to $A$. albida by Boissier in Flor. Orient., i, p. I74, are only local modifications. A. albida, being widely distributed in the vertical direction from the forest-region upwards nearly to the uppermost limit of siphonogamic vegetation, presents quite a number of varieties completely corresponding to the conditions of localities: longer internodia, larger leaves, reduced hairiness in the woods, deep-reaching roots, much-branched rhizomes, shorter, mostly very hairy, often tomentose leaves, also pale pink petals in the débris of the mountain-slopes. Under similar conditions, the same forms appear even at far separated localities. Specimens gathered by $m e$ in Algeria in the forest of cedar near Teniet el Haad at I,400 m. completely agree with plants from the Curral grande, Madeira. Abyssinian specimens from the Hedscha at 3,000-4,000 m. approach very much the var. Billardieri of Cyprus. On the other hand,

1 Halácsy in his Flora Graeca has preferred A. caucasica, Willd., quoting Willd. Enum. Suppl., 1809; but this Supplement of the Enumeratio of Willdenow was issued not earlier than 1813 , viz. one year after the publication of $A$. albida, Stev. 
forms with very tall (up to I m.) stems, as found by me on the Kilimanjaro in the upper forest at 2,600-2,900 m., have the same long-cuneate sinuatedentate leaves as specimens from the island Palma, Canary Islands. Other specimens $0.5 \mathrm{~m}$. high, collected by Volkens below the Mawensi at 2,700 m. in a clump of woods, may be reckoned undoubtedly to var. umbrosa, Boiss., being very like specimens of the sub-alpine region of M. Olympus, Bithynia. Other specimens, similar to those of Palma, were found by Dr. Ellenbeck in the Upper Galla country, in the territory of the Arussi Galla, and on the Gara Mulata near Harar at 2,500 m. Agreeing in the general shape of the leaves with the above, but distinct by its numerous smaller teeth, is forma meruensis, Engl., 3-5 dm. alta; foliis cuneiformibus, dense breviter dentatis $3^{-4} \mathrm{~cm}$. longis, $6 \mathrm{~mm}$. latis.

This form, collected on the Meru at 3,500-3,600 m. by Prof. Uhlig, has sometimes pods $4-5 \mathrm{~cm}$. long (as in the majority of the forms of our polymorphous type), sometimes only $\mathrm{I} \cdot 5$ to $2 \mathrm{~cm}$. long. Specimens grown in moist crevices of the summit of the Meru $(4,700 \mathrm{~m}$.) have also pods only $\mathrm{I} .5$ to $2 \mathrm{~cm}$. long. At the eastern base of the Kibo summit, at $4,800 \mathrm{~m}$., Prof. Uhlig gathered specimens both with long and with short pods, the first belonging to a form intermediate between meruensis, and another one which I call kiboensis. This last one-forma kiboensis, Engl., I-3 dm. alta, foliis inferioribus anguste cuneatis $2-4 \mathrm{~cm}$. longis, $3-5 \mathrm{~mm}$. latis, subintegrisshows the greatest differences from all the other forms. In fact, it would easily pass as a distinct species if there were not so many intermediate forms of the polymorphous type. It was collected also at a lower altitude $(3,300 \mathrm{~m}$.) by Prof. Hans Meyer and Prof. Volkens, also above Kibosho at $3,600 \mathrm{~m}$., being one of the last flowering-plants.

Arabis albida, then, is a polymorphous type originally descended from the same protype which $A$. alpina sprang from. Its various forms are to be found from the upper forest-region to the uppermost limit of floweringplants throughout the Mediterranean mountains, from Persia through the Caucasus Mountains to the Crimea and through the mountains of Asia Minor via Cyprus and the Greek mountains to Sicily, from there to the Atlas Mountains of Algeria and Morocco, to Madeira and the Canary Islands. The light narrow-winged seeds, being apparently suitable to be transported easily by air currents, have reached far distant summits. The seeds have found their way to Abyssinia also (for Arabia, the plant is not yet recorded up to the present); from Abyssinia, it was distributed to Galla Highland and to Kilimanjaro, where, besides the typical forms, the tall sylvatic form of $\mathrm{I} \mathrm{m}$. in height, and, on the other hand, the narrowleaved forms only $10-15 \mathrm{~cm}$. high, were developed by the influence of changed conditions of climate. These new forms are therefore of a special interest, because undoubtedly they have been formed only by the influence of new conditions of life, without any intervention of allied forms. The 
same holds good for Anthoxanthum nivale, K. Schum., and Koeleria cristata, var. supina, Pilger.

I will mention two more Cruciferae which have apparently travelled from Europe to the mountains of East Africa. Subularia monticola, A. Br., which grows in large tufts on the Dedjen, Abyssinia, at 4,000 m., in swampy and at the same time stony places, was collected again by Prof. Volkens, and later on again by Prof. Uhlig on the Kilimanjaro, close to melting snow at $3,750 \mathrm{~m}$. There is only one species resembling it, viz. Subularia aquatica, L., having a very sporadic distribution in Europe from England to southern Russia at the bottom and near the edge of lakes. Hiltner, in a careful study on these plants (Engler's Botan. Jahrb., vii, p. 264), after having compared the external and internal structure both of the aquatic and terrestrial forms of $S$. aquatica from various localities, with each other and with $S$. monticola of Abyssinia, sums up that $S$. monticola is not more different from the terrestrial form of $S$. aquatica than this from its aquatic form. Therefrom it is not improbable that birds of passage brought seeds of $S$. aquatica from Europe to the higher mountains of Abyssinia, where a somewhat different variety was developed. It should be borne in mind, however, that the genus Subularia, though classified near Lepidium as a rule, has a very isolated position. Its distribution may have been wider in former times.

A Cruciferous plant, very generally diffused in Europe, Stenophragma Thalianum, (L.) Cel., is to be found in Abyssinia and on the Kilimanjaro at the considerable altitude of $3,300-3,500$ and $3,600 \mathrm{~m}$. respectively. In Abyssinia, on the summit of M. Bachit and M. Silke at 4,000 m., a dwarf form occurs which produces flowers and fruits when only $2-3 \mathrm{~cm}$. in height. It was named Cardamine pusilla by Hochstetter, Sisymbrium pumilio by Oliver. In the 'Hochgebirgsflora des tropischen Afrika,' I classified it as a variety; at present, I should rather believe it to be only a local modification. The seeds of the Stenophragma Thalianum, common throughout the northern temperate zone, are so minute and light, that they may be spread very far by winds. The species growing also on cultivated ground, it may even have been introduced into Abyssinia with seeds of cultivated plants. Even in this case it remains a remarkable feature, that it reaches to the sub-alpine region only in Europe, whereas it produces a dwarf form on the lofty summits of Abyssinia.

Modifications of growth resembling those of $A$. albida are to be seen in Cerastium caespitosum, Gilib. (C. vulgatum, auct., $C$. triviale, Link). In every herbarium containing a large number of specimens from numerous localities, it is found that this species, while varying only little in hairiness and juncture of the sepals, has the cauline leaves now more acute, now more obtuse, varying, at the same time, from $0.5-5 \mathrm{~cm}$. in length, and from $0.2-1 \cdot 2 \mathrm{~cm}$. in width. Broad-leaved forms are especially numerous from 
Southern Europe; but also in examining Central European specimens, one sees var. elatius, Peterm., or var. nemorale, Uechtritz, having long internodes and leaves sometimes $\mathrm{I} \cdot 5^{-2} \mathrm{~cm}$. wide; further var. fontanum, (Baumg.) Gürke (=var.alpinum, Mert. et Koch = var. macrocarpum, Fenzl=longirostre, Wichura). Var. elatius occurs also in Japan.

The Berlin Herbarium contains several specimens from the Himalaya, India, Ceylon, and Java. These specimens, having been collected in mountainous regions (some of them by Prof. Warburg), more or less match the C. vulgatum as figured by Wight, Icones, $948 / \mathrm{I} 53$; that is, they have the leaves not only broad but also short, so that the length is only one and a half or twice the width. For this plant, belonging undoubtedly, as far as I can see, to caespitosum, yet differing in various directions, I propose the name var. Wightii, Engl., foliis ovalibus vel late ellipticis $2-2.5 \mathrm{~cm}$. longis, $\mathrm{I}-\mathrm{I} \cdot 2 \mathrm{~cm}$. latis.

A dwarfed form of this variety, collected on Merapi, Java, by Warburg, is only $3 \mathrm{~cm}$. in height.

C. caespitosum, Gilib., is another frequent plant of the mountains of Abyssinia, where it presents three varieties. The first one, var. octandrum, (Hochst.) Engl., is superficially almost identical with acuteleaved forms of the European C. caespitosum; but the flowers are almost always tetramerous! This plant was gathered by Schimper near Amogai, at 2,200 m., in fields and along road-sides, near Adoa, near Gaffat at 2,600 m. in fields and meadows, also near Debra Eski at $3,000 \mathrm{~m}$. In this variety the petals are constantly a little shorter than the sepals.

Flowers identical but 5 -merous are to be seen in a plant distributed in moist woods of Galla Highland, and collected by Dr. Ellenbeck and O. Neumann. It corresponds somewhat to var. elatius, Peterm., of the European forests, but has always acute leaves, as shown only rarely by the European form ; the inflorescences are also more developed, being provided, at the same time, with longer internodes than those of var. elatius. I name this plant var. scandens, Engl., caulibus scandentibus usque $5 \mathrm{dm}$. longis, foliis oblongo-ellipticis acutis; inflorescentia elongata $5^{-12} \mathrm{~cm}$. longa multiflora.

Hab. in the country of the Arussi Galla at the high plateau near Jidah at 2,600 m. a.s. 1. (Ellenbeck) and in Sidamo, near Awara, on meadows close to the bamboo-forest, at 3,100 m. (O. Neumann).

A third variety, simense, (Hochst.) Engl., having elliptical acute leaves and looser or more contracted inflorescences, is hardly to be distinguished from certain European plants. It grows on the Bachit, Abyssinia (Schimper, It. Abyss., Sect. II. 756). On the Dedjen, at about the same elevation, it passes gradually into a dwarf form of $2-5 \mathrm{~cm}$. in height only, having short internodes and crowded flowers, sometimes also petals a little 
larger, humile, A. Br. (without diagnosis in Schweinfurth, Beitr. Fl. Aethiop., p. 58). This I can consider to be only forma humile, A. Br., not even as a variety.

At the Kilimanjaro, the var. simense occurs in forms of $3^{-10} \mathrm{~cm}$. in height. It was collected near the eastern source of Garanga River at $3,700 \mathrm{~m}$. by Prof. Uhlig. Forma humile of the same variety was collected also on Cameroon Peak at 4,000 m., being the last flowering plant there.

At the Kilimanjaro, in the upper Ericinella region, at 3,300 m. (Uhlig, $\mathrm{n}$. 628 ), and on the grass-plains of $3,500-4,000 \mathrm{~m}$. (H. Meyer, n. 8), there is another form which I have seen from these localities only. It has somewhat thick, narrow-elliptical, acute leaves, very glandular inflorescences, larger petals ( $\mathrm{I} \frac{1}{2}$ the length of the sepals), and long horizontally spreading capsule twice the length of the sepals. I name this var. kilimandscharicum, Engl.; ramulis decumbentibus vel erectis superne cum pedicellis, bracteis et sepalis fere omnino viridibus densius glanduloso-pilosis ; foliis crassiusculis ellipticis acutis; petalis quam sepala $1 \frac{1}{2}$-plo longioribus; capsula quam sepala duplo longiore.

Specimens of C. caespitosum, Gilib., sent from Cape Colony are exactly like the ordinary European ones. The same applies to the specimens collected in the Transvaal by Dr. Wilms. Nor can I see any difference between the European plant and the specimens gathered by Moseley on the Challenger Expedition in the most western island of Tristan d'Acunha. Whereas specimens (without flowers) collected by Dr. Naumann, on the Gazelle Expedition on Green Mountain, Ascension, are very remarkable in having slender stems covered below with rudiments of decayed leaves and with crowded upper leaves of the same form as those of the ordinary European plant. I do not want to dwell upon the forms occurring in America and the Antarctic regions; generally, it is only to be remarked that numerous specimens gathered at the Strait of Magellan and in the Kerguelen are completely identical with European ones. Some of them show a vigorous growth.

Against all these varieties, the peculiar C. africanum, (Hook. f.) Oliv., stands apart as a species of its own, which I observed in woods and clearings of Usambara at $1,250-1,400 \mathrm{~m}$., and on Kilimanjaro at I,200$2,900 \mathrm{~m}$. Its stem ascending between shrubs and brake is often more than I m. high. The petals are one and a half times or twice the length of the sepals, the oblong-lanceolate, upwards more distinctly narrowed leaves are acute, often attenuated into a distinct point. This species, which was collected in the country of the Arussi Galla near Ladjo by Dr. Ellenbeck, which occurs also in Uluguru, on Kirunga, Ruwenzori, also on Cameroon Peak up to 3,000 m., may possibly be a descendant of $C$. caespitosum, Gilib. The C. caespitosum, Gilib., var. kilimandscharicum, Engl, above mentioned holds, indeed, about an intermediate position 
between the ordinary $C$. caespitosum and $C$. africanum, (Hook. f.) Oliv., having green sepals, larger petals, and acute leaves.

All these species mentioned so far are closely allied to plants widely distributed in Europe or more generally throughout the northern temperate zone of the Old World, growing there in the lower as well as the upper regions, whereas, in Africa, they are to be found only in the upper or uppermost belts. For several of them, their seeds being small and light, it may be assumed that they have been distributed by heavy gales; still stronger seems the argument that the first transport from Europe or Western Asia to the upper treeless regions of Africa has been effected by birds of passage, the seeds adhering to their feet with soil or by hairs and bristles to the plumage, and that they were dispersed afterwards from mountain to mountain by winds. It is not impossible that in this manner seeds are reaching Africa from the northern temperate zone even at the present time. But most of these species are not only to be found now on several of the high mountains of Africa, but they appear there in forms constantly distinct from the European ones. It seems reasonable, then, to assume that immigration took place at some earlier date. On the other hand, from our experiences of alpine plants cultivated in the lowlands and growing there more vigorously, I am led to the opinion that the forms modified by a longer period of vegetation and by higher temperature have arisen in a relatively shorter length of time. The principal reason for my supposing that immigration took place at some earlier date is the probable state of external conditions during that pluvial epoch as assumed by geologists, which must have been more favourable for any immigration of forms of the temperate zone than the conditions prevailing at the present time. Extensive alluvial deposits of a recent date, traces of a formerly larger amount of water in the present lakes and rivers, traces of a wider extension of African glaciers in the past (Hans Meyer on Kilimanjaro, in Zeitschr. Gesellsch. Erdkunde, Berlin, 1904, p. 193) serve as a proof of this pluvial epoch. During this period the forests must have extended further down, the treeless tracts spread to lower regions. At this time, then, the areas suitable for plants of more temperate zones were larger and approaching each other more, though not really continuous. There has always been also a large region between Abyssinia and Southern Europe or Western Asia which has never been suited to harbour the highland plants mentioned by me.

All these highland forms have a common feature in being systematically isolated in Tropical Africa, whereas there is quite a number of allied species in the temperate zone. This is easily to be accounted for, because, in the present time as well as during the pluvial epoch, only the loftiest mountains of Tropical Africa afforded conditions which 
enabled any seed carried from the northern temperate zone to this continent to germinate and to grow.

The differences to be seen in most of these highland forms, as compared with their relatives of the northern temperate zone, are always in harmony with the different climatic conditions. The temperature of the alpine region of Kilimanjaro or Ruwenzori may be somewhat like that of our high Alps during the summer time; but there is this great difference that, in the snow-region of Africa, the ground is free from snow several months longer than in the Alps, and that, during the dry period, the strong insolation, even when acting only a few hours of the day, dries up the soil very much. Only in crevices and small ravines more favourable conditions exist for the development of turf-forming hygrophilous plants such as are so abundant on our alpine meadows. The variety of such plants is at the present time (and has been also during the pluvial period) much inferior to that on the mountains of the northern temperate zone, where large continental areas allowed a rich development of the plants wanting only little warmth for existence, and where repeatedly climatic changes were responsible for far-reaching migration of the highland forms originally evolved in the various centres of evolution.

There is also very little in common between the alpine flora of the lofty mountains of Africa and the highland flora of the Mediterranean mountains, where the arctic-alpine plants are wanting or very scarcely represented. A number of genera, it is true, are to be found also on the mountains of Tropical Africa, viz. Trifolium, Scabiosa, Cephalaria, Campanula, Crepis, Hypericum, Micromeria, Anemone, Carduus, Centaurea, Helichrysum, and a few others. Of Helichrysum, a few species are marked even by their woolly tomentum. But we do not in the least find the extraordinary amount of woolly or tomentose and spinous perennials so conspicuous on the mountains of Asia Minor and Central Asia, on the mountains of Greece, and even on the Sierra Nevada; nor are the leafless broom-like shrubs prevailing in the hilly parts of the Mediterranean countries to be seen on the mountains of Tropical Africa. It is obvious that this feature is explained by the much more intense dryness of the atmosphere and of the soil during the Mediterranean summer. From the same cause, only a few types of the steppe may be seen ascending to the alpine region in Tropical Africa, although access seems easy enough. How very different in the high mountains of Asia Minor, where the types of the steppe (Astragalus, Cousinia, Artemisia, Statice, Labiatae, Boraginaceae, Cruciferae, Umbelliferae, bulbous plants) prevail to an astonishing extent! In Tropical Africa we find only grasses of the steppe ascend to higher altitudes. Also Ericaceae and small-leaved shrubs of a similar habit are more abundant, but these belong to types more or less developed in Southern Africa. 
After all, the highland flora of Tropical Africa is not very rich in peculiar components derived from types of the lower regions. This, again, is the cause of the enormous extension of a few species and the amount of yet tenantless ground in the upper regions. Such ground has been always at the disposal of any seed brought from anywhere by wind or birds as long as it kept its power of germination. Further, I may be allowed to refer to some species of the forest-region of Tropical Africa which, being likewise nearly allied to such of the temperate zone, have undoubtedly not reached Tropical Africa by man's intervention.

Such a European type widely distributed in the forests of Africa is Sanicula europaea. When observing it in Usambara and on Kilimanjaro, I tried to find out if there were any differences between the African plants and the European ones. The specimens not uncommonly attain a height of about $60 \mathrm{~cm}$.; they frequently possess a leafy stem, they have sometimes lateral branches, and the leaves have always segments much narrowed from the base towards the apex; the flowers are mostly purplish-brown, the lateral branches of the inflorescence often much elongated. The same characters are to be found in Abyssinia, on Ruwenzori, Cameroon Peak, in the mountains of Nyassaland, Natal, and Cape Colony, at the Comoro Islands and in Madagascar. But the purplish colour of the petals is not constant. And some specimens collected by Medley Wood in Natal at about $1,000 \mathrm{~m}$. a. s. l. show only one leaf on the simple stem. On the other hand, even in Germany (near Eisleben, Lagow, Rastatt-Herb. Berlin), there are vigorous specimens with several cauline leaves and the same cutting of the leaves which is the general rule in the African specimens. Some specimens from Daghestan and the mountains of Pontus approach even more the African plant, and, at the same time, the S. elata, Hamilt., of India. This is simply brought under S. europaea by C. B. Clarke (in Hooker, Flora of Brit. India, ii, 670), while Hooker fil. called it S. europaea, var. elata on the labels of his Himalayan collections. I incline to adopt Hooker's terminology for the African plant also. This was named var. capensis by Chamisso and Schlechtendal in Linnaea I. (1826) 352. But the name of Sanicula elata, Hamilt., being published as early as 1825 , is to be recommended, so much the more as it is indicative of the habit and, at the same time, does not favour any of the many countries where the variety occurs. In Asia this variety is to be found in the mountains of Pontus and Daghestan, Himalaya, British India, and Ceylon, in Java and Sumatra (S. javanica, Bl., S. montana, Reinw.), in Central China and Japan; it seems to be very difficult to classify any subvarieties.

All the differences of these Saniculae from the European form seem obviously to be called forth by the longer vegetation-period as afforded 
in the mountain-woods of the tropical and sub-tropical countries. The wide distribution is accounted for by the fruits being densely covered with hooked bristles adhering to the plumage of birds.

Sambucus, as well as other Caprifoliaceae, has long been unknown from Tropical Africa. Therefore, when examining the valuable collection of Fischer collected at Abori, Kikuyu, it was very surprising to me to find a species of Sambucus exactly coinciding with S. ebulus in habit, but different by unusually elongated nearly cylindrical fruits and by yellow anthers. Last year I received the same plant from Mr. C. F. Elliott, the Director of the Forest Department in the Uganda Protectorate; he collected it in the hills north of Nairobi. There is no doubt of its close affinity to Sambucus ebulus, which is rather an isolated type of the genus ; at the same time it is quite certain to be indigenous in these regions of Africa, because no European had settled at Kikuyu at the time of Fischer's travels. Further, the idea must be refuted that this African Sambucus is a relict form. There is no doubt that it came to the mountains of Equatorial Africa from its northern and Mediterranean area (extending from England and Gotland via Central and Southern Europe as far as Asia Minor and Persia and Algeria) quite in the same manner as it reached Madeira and the North-western Himalaya.

In passing over to the Himalayan region, as well as in some localities of Asia Minor, the species has developed yellow anthers instead of the violet ones as shown by the ordinary forms. Our African specimens have the inflorescences densely clothed by rusty hairs; they have narrow linear bracts and also yellowish anthers. Furthermore, the oblong-ovoid green fruits afford a striking character: in all the specimens, however, both Fischer's and those collected by Elliott seventeen years later, these fruits contain only unfertilized ovules. Still, even leaving out of consideration these abnormally developed fruits, we may well consider the plant as a variety more recently evolved, var. africanus, Engl.; foliis robustis, foliolis elongato-lanceolatis acuminatis; inflorescentia dense ferrugineopilosa, bracteolis ramulos fulcrantibus lineari-lanceolatis, antheris flavis.

English East Africa: Abori (Fischer, n. 327) ; Kikuyu (C. F. Elliott, n. 12,177$)$.

Veronica chamaedrys, L., widely distributed in Europe and occurring in Asia Minor also, shows only slight variations of hairiness and cutting of the leaf-margin throughout these countries. Also $V$. chamaedryoides, Bory et Chaub., a native of the fir-region of M. Parnassus, M. Taygetus, of Thasus, of Northern Laconia, Asia Minor, differs from the common form by denser pubescence only. Against it, Veronica micrantha, Hffgg. et Link, found in Portugal, near Beira, must rather be kept as a distinct species derived from $V$. chamaedrys, owing to the short peduncles, otherwise not seen in European forms, and to the smaller flowers. Both these characters, 
combined with erect habit, freer branching, and more scanty pubescence of the leaves, are to be seen on a plant collected first by Volkens on the Kilimanjaro, afterwards above Sakare, Western Usambara, by myself, and in Coromma Valley, Galla Country, by Riva on Ruspoli's expedition. Being unable to acknowledge the specific rank of $V$. chamaedryoides, Bory et Chaub., I had named this plant $V$. chamaedryoides, Engl. (in Pflanzenwelt Ostafrikas, C, 358). Still, in order to avoid any possible confusion, I would rather drop this name now and substitute afrochamaedrys, Engl., in its place. We do not know any species in Tropical Africa which could possibly be compared with it or considered to be its ancestor. For Veronica abyssinica, Fresen., a frequent herb in the woods of Abyssinia, Gallaland, East Africa, and Cameroon, belongs to another affinity (that of the Europaeo-mediterranean $V$. montana, L.). The flat seeds of $V$. afrochamaedrys, being still somewhat smaller than the I mm. long seeds of $V$. chamaedrys, may easily be carried away on the feet of birds. Therefore it is no bold speculation to assume that $V$. chamaedrys from the Mediterranean transported to Gallaland (probably to Abyssinia before that time) developed itself to $V$. afrochamaedrys. On this occasion, $V$. filiformis may be mentioned, which occurs in Abyssinia Highland, in America, and the Caucasus Mountains, and also $V$. violifolia, Hochst., allied to $V$. agrestis, $\mathrm{L}$.

Further, I should like to bring forward the interesting fact, reported by me in Sitzber. k. Preuss. Akad. Wiss., February I8, I904, that the wellknown Populus euphratica, Olivier, of the Mediterranean region (in the broadest sense) has nearly reached the equator (at Korokoro, Upper Tane River), and has produced there a peculiar large-fruited form named by me sub-sp. Denhardtiorum (in Notizbl. k. Bot. Gart. Berlin, II (I898), 2I8). Populus euphratica, Olivier, is distributed from Songaria to Palestine and to Western Tibet; further, it is found on the Morocco-Algerian border, and has been recorded from the Libyan Desert by Ascherson, 1877. It is likely to be found also in Arabia on further investigation in that country. But at any rate there remains a wide gap of about twenty-two to twentythree degrees of latitude from there to the African stations of $P$.euphratica. The African sub-species approaches somewhat the Indian specimens in having a long petiole and ovate remotely sinuate leaves ; it differs, however, most decidedly in having short (not more than $3 \mathrm{~cm}$. long) fruiting-spikes and capsules nearly $1 \mathrm{~cm}$. long, 6-7 mrn. thick. It is another instance of a species having been modified by advancing from the temperate zone to its new situation. The wider expansion of the steppes in Africa being the result of more modern geological changes, it is safe to assume that sub-sp. Denhardtiorum is a younger type than $P$. euphratica of the northern temperate zone.

In conclusion, I should like to add to the above-mentioned cases 
a few more cases of disjointed distribution which seem to be the result of some other evolution than that of the species considered so far.

One of the most prominent instances of disjointed range is presented by the genus Canarina. For a long time, only one species was known, C. campanula, Lam., a plant very characteristic by its large, bell-shaped, orange-coloured flowers. On the Canary Islands, it is very frequent in some places; it is often cultivated in greenhouses. It was considered to be an isolated type of the Campanulaceae, an endemic product of the Canary Islands. But quite recently, a second species was discovered by Dr. Stuhlmann on the Emin Pasha expedition: C. Eminii, Ascherson (in Sitzber. naturf. Freunde, Berlin, I892), which was found in the forest-region of M. Ruwenzori, at $2,500 \mathrm{~m}$. a.s.1. A third species, C. abyssinica, more allied to the second one, was collected by Dr. Ellenbeck, who accompanied as the physician the expedition of Baron Carl von Erlanger to Somaliland and Gallaland. It was found in Galla Highland, west of Lake Abbaya, at 2,000-2,500 m. a. s. l., later on also more towards the west by O. Neumann. These plants, having berries eaten by men on the Canary Islands and likely to be consumed by birds also, may be assumed to have been spread from mountain to mountain by birds. The rather striking differences, however, between the Canarian species and the two species of the African continent seem to indicate that Canarina is an older genus whose species, having travelled in more remote periods, may have had wider areas formerly. It is not impossible that this genus was indigenous even to the Mediterranean region at some distant period. I am inclined to the consideration of this hypothesis by the distribution of Sempervivum arboreum, which is spread throughout the southern Mediterranean countries, from Portugal and Spain as far as Cyprus. By natural affinity it is connected with S. chrysanthum, Hochst., a native of Abyssinia, and at the same time with a number of species (viz. S. canariense, L., S. urbicum, Chr. Smith, S.palmense, (Webb) Christ, S. cuneatum, (Webb) Christ, S. ciliatum, Willd., S. percarneum, Murray, S. tabulaeforme, Haw.) which are indigenous to the Canary Islands or (S. glandulosum, Ait., S. glutinosum, Ait.) which are natives of Madeira.

With regard to the species or varieties I have enumerated above (Canarina excluded), I may be allowed to make some general remarks. We may call such modifications CLIMATICAL ADAPTATIONS, but only in this sense, that this adaptation is a passive one, caused by the physical conditions of the climate, not an active one, which would correspond to the views of Lamarckians.

The first condition for such modifications is that the fruits or seeds are such that, without losing the faculty of germination, they can be easily transported to regions removed from the locality where they were indigenous before.

This will in many cases happen accidentally. It is also only accidental, 
when the seeds find place and conditions suited for germination and climatic conditions for their development, which are not too different from those of their former native country.

I am convinced that in such cases the somewhat different climate is the cause of all or at least of a part of the modifications. Sometimes in connexion with these new variations are also to be observed (cf. Cerastium caespitosum), which may become the beginning of other new forms. The constancy of such climatical adaptations may be a different one and often become fixed through a geological period. I may add that systematic studies have also convinced me that many of the xerophytes must have originated from mesophytes, and that a good deal (I do not say all) of the qualities of xerophytes, which are usually called adaptations for protection against a dry climate, are caused by this climate itself (cf. A. Engler, Pflanzenwelt von Deutsch-Ostafrika, A, p. 25). 


\section{$2 \mathrm{BHL}$ Biodiversity Heritage Library}

Engler, Adolf. 1904. "Plants of the northern temperate zone in their transition to the high mountains of tropical Africa." Annals of botany 18, 523-540. https://doi.org/10.1093/oxfordjournals.aob.a088974.

View This Item Online: https://www.biodiversitylibrary.org/item/234469

DOI: https://doi.org/10.1093/oxfordjournals.aob.a088974

Permalink: https://www.biodiversitylibrary.org/partpdf/318772

\section{Holding Institution}

Smithsonian Libraries

\section{Sponsored by}

Biodiversity Heritage Library

\section{Copyright \& Reuse}

Copyright Status: Not in copyright. The BHL knows of no copyright restrictions on this item.

This document was created from content at the Biodiversity Heritage Library, the world's largest open access digital library for biodiversity literature and archives. Visit BHL at https://www.biodiversitylibrary.org. 